\title{
Correction to: A spectral-velocity-based combination- type earthquake intensity measure for super high-rise buildings
}

\author{
Yantai Zhang ${ }^{1} \cdot{\text { Zheng } \mathrm{He}^{1,2} \cdot \text { Youfu Yang }}^{1}$
}

Published online: 13 November 2017

(C) Springer Science+Business Media B.V., part of Springer Nature 2017

\section{Correction to: Bull Earthquake Eng https://doi.org/10.1007/s10518-017-0224-5}

The following changes are needed to demonstrate more clearly and precisely the use of sources in Eqs. (14), (15) and (17) in Sect. 6.2 Sufficiency of the original publication:

\begin{tabular}{|c|c|c|}
\hline Position & Original & Revised \\
\hline $\begin{array}{l}\text { Before } \\
\text { Eq. (14) }\end{array}$ & $\begin{array}{l}\text { "Therefore, the equation can be } \\
\text { simplified as": }\end{array}$ & $\begin{array}{l}\text { "Therefore, the equation can be simplified as (Jalayer } \\
\text { et al. 2012)": }\end{array}$ \\
\hline $\begin{array}{l}\text { Before } \\
\text { Eq. (15) }\end{array}$ & $\begin{array}{l}\text { "... with an average over a suite of } \\
\text { n real ground motion records." }\end{array}$ & $\begin{array}{l}\text { "...with an average over a suite of n real ground motion } \\
\text { records (Jalayer et al. 2012)." }\end{array}$ \\
\hline $\begin{array}{l}\text { Before } \\
\text { Eq. (17) }\end{array}$ & $\begin{array}{l}\text { "Hence, the RSM can } \\
\text { approximately be expressed as": }\end{array}$ & $\begin{array}{l}\text { "The following can be understood on the basis of the } \\
\text { conceptual framework of Jalayer et al. (2012) and was } \\
\text { further clarified through a detailed derivation by } \\
\text { Ebrahimian et al. (2015)": }\end{array}$ \\
\hline
\end{tabular}

The original article can be found online at https://doi.org/10.1007/s10518-017-0224-5.

Zheng He

hezheng1971@126.com

Yantai Zhang

atai1991@126.com

Youfu Yang

youfuyang@163.com

1 Department of Civil Engineering, Dalian University of Technology, Dalian 116024, China

2 State Key Laboratory of Coastal and Offshore Engineering, Dalian University of Technology, Dalian 116024, China 
These references have been listed in the references of the original online paper.

\section{References}

Ebrahimian H, Jalayer F, Lucchini A, Mollaioli F, Manfredi G (2015) Preliminary ranking of alternative scalar and vector intensity measures of ground shaking. Bull Earthq Eng 13(10):2805-2840. https://doi. org/10.1007/s10518-015-9755-9

Jalayer F, Beck JL, Zareian F (2012) Analyzing the sufficiency of alternative scalar and vector intensity measures of ground shaking based on information theory. J Eng Mech 138(3):307-316. https://doi.org/ 10.1061/(ASCE)EM.1943-7889.0000327 